\title{
U-boats: The Unsuccessful Role in WWII
}

\author{
Jinghan Cheng
}

\author{
Europe in the Age of World Wars, Shandong Experimental High School \\ Jinan, China, 1744535203@qq.com
}

\begin{abstract}
The essay examines the factors that led the Nazi German U-boats to their ultimate failure of changing the war progress in World War Two with the application of primary and secondary sources, in addition to the opinions of other historians.
\end{abstract}

Keywords: World War Two; Nazi Germany; German U-boats; Wolfpack; Karl Doenitz; Winston Churchill

\section{INTRODUCTION}

During the Second World War, the infamous Nazi German U-boats were the terror in the Atlantic Ocean. Shipping fleets that sail on sea routes that brought supplies to Great Britain lived in terror of these underwater assassins, and not without cause--some were often found to be blown up in sight of land and many famous battleships that cause tens of millions to build were sunk because of a few small submarines. For a time, U-boats seemed to be the most powerful and perfect weapon in a naval fleet--it was relatively cheap to build and can afflict terrible damage to the enemy's fleet and morale, plus they could creep near or away from enemy ships without much notice. The torpedoes they carry were deadly since they strike the ships under the waterline and thus can easily cause the ship to capsize or break up. However, although it was true that German Uboats did indeed cause some trouble in the early days of the war, they were not very effective and could not destroy the morale of the British people.

A key figure in the German submarine warfare campaign was Karl Doenitz, who was the "Commander of the Submarines" (Befehlshaber der Unterseeboote or $\mathrm{BdU})$ at the start of the war. He was captured by the British during one operation in World War One and remained a prisoner of war (POW) until the war was over. While in the POW camp, he formulated the idea of Rudeltaktik, better known as the wolf-pack, which involved numerous submarines that were congregated together to form an attack formation when enemy convoy was spotted. The idea was still rudimentary at that time, but it would soon be perfected with war-time experience after WWII started. At the end of the war, Doenitz returned to Germany and continued to serve in the navy, or the Reichsmarine, of the Weimar Republic during the interwar period. Because the Germans lacked the necessary radios for the cooperation of submarines during World War One, the wolf-pack tactic had been difficult to put into practice. Things changed when the Ultra High Frequency (UHF) Transmitters were developed during the interwar period and was combined with the famous Enigma machine to encode the messages. Furthermore, the idea was developed that the wolf-pack should attack at night and on the surface of the ocean. Even so, this tactic would depend heavily on the production of sufficient numbers of U-boats, which proved to be unsatisfactory in Germany before the start of World War Two.

\section{MILITARY INEFFECTIVENESS}

The primary reason was that the U-boats were not militarily effective. To be sure, the U-boats in World War II were a great improvement over the ones in World War I. And after the signing of the Anglo-German Naval Agreement of 1935, which restricted the tonnage of the German submarines at $45 \%$ of that of the British Royal Navy, the German Navy had 12 type II U-boats, 2 type Is, and 10 type VIIs in the summer of 1935. Type VII, especially, was favoured by Karl Doenitz because it was "easy and safe to handle" with "the greatest possible fighting power" [1]. With 16 knots on the surface and equipped with 12 or 14 torpedoes, type VII was an ideal model for Doenitz's wolfpack tactic. However, the German Naval High Command still held the belief that U-boats should fight alone instead of in groups for fear of breaking the wireless silence and they deemed necessary to build large U-boats that weighed 2,000 tons"U-cruisers" as Doenitz named them-that could fight gun battles on the surface. These conflicting views on the use and tactical handling of the U-boat arm in war, and the subsequent divergence of opinion about the most 
advantageous building program, persisted for several years after 1935 until World War Two started. As a result, the naval Commander-in-Chief, Grand Admiral Erich Raeder, feeling that the issue had not been satisfactorily clarified, decided to postpone making any decision about the German U-boat construction program. In addition, the rearmament priority was given mainly to the Heer (the German army) and the Luftwaffe (the German air force); thus, the building of the U-boats was reduced and was clearly reflected in the year-by-year delivery number of U-boats to the German Navy:

$$
\begin{aligned}
& \text { 1935-14 U-boats } 1936 \text {-21 U-boats } \\
& \text { 1937-1 U-boat } \\
& \text { 1938 - 9 U-boats } 1939 \text {-18 U-boats [2] }
\end{aligned}
$$

The numbers were not satisfactory and beyond the 300 U-boats estimated by Doenitz needed to "achieve decisive results" if Great Britain "adopted a world-wide convoy system" [3]. He argued that at least three hundred U-boats were needed in order to successfully wage war against Allied shipping. In arriving at this figure, Doenitz assumed that at any given moment one hundred U-boats would be in port for overhaul and to give their crews a period of rest, a further hundred would be on their way to or from the theatre of operations, and the remaining hundred would be actively engaged in operations against the enemy. And so, even before the war started, Doenitz's plan of cutting of the supply line of Great Britain was doomed.

\section{TORPEDO CRISIS}

In addition to the aforementioned situation, problems regarding the torpedoes also aroused when the U-boats were put to use into the war. Especially during German's Operation Weserübung in Norway in April of 1940. At first to unknown reasons, the magnetic torpedoes of the U-boats constantly misfired. These torpedoes either exploded early or simply ran off course. According to Doenitz, during the Court Martial proceedings, the Inspector of Torpedoes had concluded that " 34.2 per cent [of the misses was] due to torpedo failure" [4]. The uncertainty of the magnetic torpedoes led Doenitz to "forbade all use of magnetic pistols" and "only contact firing would be used" [5]. But already the U-boats had lost many precious opportunities due to the failure of the torpedoes like the attack on "[HMS] Ark Royal on September 14, 1939, and [HMS] Nelson on November 30 , 1939" that might had been able to alter the war progress.

\section{EARLY SUCCESS}

But the U-boats were not without success. Following the surrender of France in 1940, the numerous ports on the west coast of France were opened to U-boats as ideal bases to strike the Atlantic supply line. What follows was what called the 'Die Glückliche Zeit' (the 'Happy Time'). From July 1940 to the end of October, 282 Allied ships were sunk off the north-west approaches to Ireland for a loss of 1,489,795 tons of merchant shipping [6]. Doenitz's U-boats and his wolfpack tactic seemed to be unstoppable.

Here, it is necessary to understand how the wolfpack tactic worked. Basically, when a U-boat had detected a supply fleet, it would maintain contact and sent high frequency transmissions to other U-boats around the area. Doenitz's headquarters would also be informed and the U-boats would then surround the ships from all sides and attack them at night from the surface.

The primary reason for this successful period was because the British lack effective ways to detect the presence of U-boats and ASIDC (sonar) could only detect submerged U-boats.

\section{BRITISH COUNTERATTACK}

But the "Happy Time" did not last long. Two important factors attributed to the British anti-submarine efforts. The first was the success of codebreakers in deciphering the Kriegsmarine's code at Bletchley Park. The second was the installation of the High-frequency direction finding, better known as "huff-duff", on convoys, which allowed shipping fleets to defend themselves against the U-boats' attacks by intercepting the high-frequency signals the U-boats send to the headquarter and can thus locate the U-boats and their bearings. Combined with the deciphered messages, The British was able to map out the location and the course of U-boats. The effectiveness of this combined strategy was proved when merchant ship losses dropped by over two-thirds (from 65 to 21) in July 1941 [7].

The Allies also made great efforts at developing antisubmarine weapons. At the start of the war, depth charges were the only weapon that can be used to damage submerged U-boats. However, by the late of 1942, convoy ships had equipped ahead-throwing antisubmarine weapons like hedgehogs and later improved weapons like squids. Leigh lights installed on aircrafts further helped the attack of U-boats during night time. Uboats would be immediately illuminated by the light and will be attacked by depth charges. This device contributed to a drop of Allied shipping losses from 600,000 tons to 200,000 tons per month [8].

Yet, the key to Allied victory lay in the deciphering of the messages encoded by the German Enigma machine. As aforementioned, the Germans U-boats made wide use of the Enigma machine to transmit messages between each other and the German Naval High Command, which was a crucial part in carrying out the wolf-pack tactics. If the Allies could decode the intercept messages, it would greatly improve the accuracy of locating the U-boats. But deciphering the Enigma 
machine was no easy task. In all, the Enigma had about $158,962,555,217,826,360,000$ different settings. It was well known that the Germans held great faith in the Enigma, which was part of the reason why they used it so extensively for all branches of the Wehrmacht (armed forces of Nazi Germany). In early 1941, thanks to the work of three brilliant mathematicians from Poland before the war started, as well as cipher texts found aboard captured U-boats during late 1940, the cryptographers in Bletchley Park were able to decipher U-boat radio messages.

The climax of the Atlantic campaign happened between March 1943 to May 1943, which proved to be a disastrous period for the U-boats. Especially in May, which was also dubbed "Black May", 41 U-boats lost in one month [9] while only 49 Allies ships were sunk [10]. Faced with the disaster, Doenitz was forced to call off the operation in North Atlantic, saying, "We had lost the Battle of the Atlantic" [11]

\section{BRITISH DETERMINATION}

In retrospect, it is clear that the U-boat campaign had failed in cutting off the British supply line by spring of 1943. But what had been its impact? The U-boats were never designed to face the Royal Navy in a direct battle, especially after Hitler's plans to invade the British Isles were abandoned. Instead, Doenitz had focused on the tonnage war, aiming to sink as many ships as possible, preferably supply ships that sustained food and fuel for Great Britain. The plan was to create enough terror and starvation in the British people and force them to terms, if not surrender. This might have worked, but as we can see, the U-boats efforts ultimately were too few and could not keep up with the massive production capacity of the Allies as the war stretched on. Lost tonnage notwithstanding, it makes sense to examine British morale before the time when the war had shifted to be in their favor. What about earlier, especially during the two happy times? Had the German campaign made life intolerable for the British people? Had the attacks by the U-boats ever gotten close to convincing the British people to surrender? One critical factor in determining the answers to these questions is the attitude held and promulgated by the leader of Britain. Luckily, the British had a determined leader that would fight on no matter the odds. Sir Winston Churchill made clear in his speech on May 13, 1940 to the House of Commons as Prime Minister that the aim of the war "is victory, victory at all costs, victory in spite of all terror, victory, however long and hard the road may be; for without victory, there is no survival" [12]

After France had surrendered, Churchill knew that Nazi Germany's next target was Great Britain, yet he was determined to fight on. He delivered a speech on June 18, 1940 to the House of Commons that include the following:
Hitler knows that he will have to break us in this island or lose the war. Let us therefore brace ourselves to our duty and so bear ourselves that if the British Commonwealth and Empire lasts for a thousand years, men will still say: "This was their finest hour" [13].

The British spirit, although tested by countless obstacles, did not falter, nor did the U-boats' attacks broke it, but fought back courageously. As a result, the plan to force the British into surrendering never succeeded and the U-boats, ultimately, had failed.

\section{HISTORIANS' OPINIONS}

Some historians like G. H. Persall believed that "the Germans were close" to economically starving England, but they "failed to capitalize" on their early war successes [14]. Others, like Levine, who states this is "a misperception", and that "it is doubtful they ever came close" to achieving this [15]. The reason for the misperception that the German blockade came close to success may be found in post-war writings by both German and British authors. Clay Blair attributes the distortion to "propagandists" who "glorified and exaggerated the successes of German submariners", while he believes Allied writers "had their own reasons for exaggerating the peril" [16].

\section{CONCLUSION}

In the Second World War, the U-boats sank a total of 3,500 Allied merchant ships, which amounts to 14.5 million gross tons and 175 Allied warships were sunk and some 72,200 Allied naval and merchant seamen lost their lives [17]. On the other hand, the Germans lost 783 U-boats and approximately 30,000 sailors killed, three-quarters of Germany's 40,000-man U-boat fleet [18]. Although the U-boats inflicted great losses on the Atlantic supply line, the damage was simply not enough to break the supply line or the spirit and the determination of the British. However, because their attacks created such a deep impression among people, their role in the great war was often exaggerated. Ultimately, without a powerful navy or airpower as support, the U-boats could only hinder, but could not prevent, the victory of the Allies.

\section{REFERENCES}

[1] Doenitz, Karl. Memoirs: Ten Years and Twenty Days. Pen \& Sword Books, 2012. p.29

[2] Doenitz, Karl. Memoirs: Ten Years and Twenty Days. Pen \& Sword Books, 2012. p.31

[3] Roskill, S. W. (1957) [1954]. Butler, J. R. M. (ed.). The War at Sea 1939-1945: The Defensive. History of the Second World War United Kingdom Military 
Series. I (4th impr. ed.). London: HMSO. OCLC 881709135.

[4] Doenitz, Karl. Memoirs: Ten Years and Twenty Days. Pen \& Sword Books, 2012. p.93.

[5] Doenitz, Karl. Memoirs: Ten Years and Twenty Days. Pen \& Sword Books, 2012. p.101.

[6] Blouet, Brian W. 2012. Global Geostrategy: Mackinder and the Defence of the West. London: Routledge.

[7] “ Ship Losses by Month - Uboat.net." n.d. Uboat.net. https://uboat.net/allies/merchants/losses_year.html.

[8] “The Leigh Light - Technical Pages - Fighting the U-Boats - Uboat.net." n.d. Uboat.net. https://uboat.net/allies/technical/leigh_light.htm.

[9] “U-Boat Losses 1939-1945 - Fates - German UBoats of WWII - Kriegsmarine - Uboat.net." n.d. Uboat.net. https://uboat.net/fates/losses/.

[10] “ Ship Losses by Month - Uboat.net.” n.d. Uboat.net.

https://uboat.net/allies/merchants/losses_year.html.

[11] Costello, John; Hughes, Terry (1977). The Battle of the Atlantic. London: Collins. OCLC 464381083

[12] "Blood, Toil, Tears and Sweat". International Churchill Society (ICS). (London: Bloomsbury Publishing plc.) 13 May 1940.

[13] "Their Finest Hour". International Churchill Society (ICS). (London: Bloomsbury Publishing plc.) 18 June 1940.

[14] Pearsall, G. H. (1994). The Effects of World War II Submarine Campaigns of Germany and the United States; A Comparative Analysis. https://apps.dtic.mil/sti/citations/ADA283407: Naval War College Newport, Rhode Island. p. 7.

[15] Levine, Alan J. (1991). "Was World War II a nearrun thing?". In Lee, Loyd E. (ed.). World War II: crucible of the contemporary world. M. E. Sharpe. ISBN 978-0-87332-731-2.

[16] Blair, Clay, Jr. (1996a). Hitler's U-Boat War: The Hunters 1939-1942. I. Cassell. ISBN 978-0-30435260-9.

[17] White, David F. (2007). Bitter Ocean: The Battle of the Atlantic, 1939-1945. New York: Simon \& Schuster. ISBN 978-0-7432-2930-2.

[18] Bennett, William J. 2007. America, the Last Best Hope. Volume II, from a World at War to the Triumph of Freedom, 1914-1989. Nashville, Tn: Thomas Nelson. ISBN 978-1-59555-057-6. 